\title{
ANTIPROLIFERATIVE, ADME AND POTENTIAL IN SILICO G6PDH INHIBITORY ACTIVITY OF NOVEL 2-(1-BENZOFURAN-2-YL)-4-(5-PHENYL-4H-1, 2, 4-TRIAZOL-3-YL) QUINOLINE DERIVATIVES
}

\author{
SANTOSHKUMAR S.,1 MANJULATHA K., ${ }^{2}$ SATYANARAYAN N. D., ${ }^{*}$ ANANTACHARYA R.,1 HARISHKUMAR S.,1 \\ HARISHKUMAR H. N., ${ }^{3}$ YALLAPPA S. ${ }^{4}$ DHANANJAYA B. L. ${ }^{5}$
}

1Department of Pharmaceutical Chemistry, Kuvempu University, Post Graduate Centre, Kadur 577548, Chikmagalur, Karnataka, India, ${ }^{2}$ School of Life Science, University of Hyderabad, C. R. Rao Road, Gachibowli 500046, Hyderabad, Telangana, India, ${ }^{3}$ Department of

P. G. Studies and Research in Chemistry, School of Chemical Sciences, Jnana Sahyadri, Kuvempu University, Shankarghatta 577451,

Shivamogga, Karnataka, India, ${ }^{4}$ Department of P. G. Studies and Research in Industrial Chemistry, School of Chemical Sciences, Jnana Sahyadri, Kuvempu University, Shankarghatta 577451, Shivamogga, Karnataka, India, ${ }^{5}$ Toxinology/Toxicology and Drug Discovery Unit, Centre for Emerging Technologies (CET), Jain University 562112, Kanakpura Taluk, Ramanagara District, Karnataka, India Email: satya1782005@gmail.com

Received: 19 Aug 2016 Revised and Accepted: 21 Sep 2016

\section{ABSTRACT}

Objectives: Synthesis of new 2-(1-benzofuran-2-yl)-4-(5-phenyl-4H-1, 2, 4-triazol-3-yl) quinoline and its derivatives for antiproliferative potential against cancer cells.

Methods: The general methods were employed for the synthesis and the structures were confirmed by IR, ${ }^{1} \mathrm{H}-\mathrm{NMR}$, ${ }^{13} \mathrm{C}-\mathrm{NMR}$ and mass spectral analysis. The antiproliferative activity was performed by 3-(4,5-dimethylthiazol-2-yl)-2,5-diphenyltetrazolium bromide (MTT) assay and molecular docking study were performed by Auto Dock Tools. In silico Absorption-Distribution-Metabolism-Excretion-Toxicity (ADMET) study for the drug, likeliness was carried out on ACD/lab-2.

Results: The compound 31 showed 44, 44, 38 and $37 \%$ inhibition against MCF-7, HepG2, Colo205 and HeLa cell lines, respectively; whereas, the compounds $3 \mathrm{i}$ and $3 \mathrm{j}$ exhibited 49 and $42 \%$ inhibition against MCF-7 cell line. The molecular docking study revealed that the compound $3 \mathrm{i}$ has the lowest binding energy (-8.60 Kcal mol-1), suggesting to be potentially best inhibitor of Glucose-6-phosphate dehydrogenase (G6PDH). The in silico ADME analysis also revealed that compound $3 i$ does not violate any of the Lipinski rules of five and has the best stimulative human colonic absorption up to $95 \%$.

Conclusion: The study reveals that the compounds containing benzofuran coupled nitrogen heterocycles are essential for activity as they possess excellent drug-like characteristics.

Keywords: Benzofuran, Quinoline, Triazole, Antiproliferative, Glucose-6-phosphate dehydrogenase

(C) 2016 The Authors. Published by Innovare Academic Sciences Pvt Ltd. This is an open access article under the CC BY license (http://creativecommons.org/licenses/by/4. 0/) DOI: http://dx.doi.org/10.22159/ijpps.2016v8i11.14791

\section{INTRODUCTION}

Cancer is one of the most severe diseases and is the major cause of human death [1]. According to a new version of GLOBOCAN 2012 and IARC's online database, a total of 14.1 million new cancer cases and 8.2 million cancer-related deaths [2] were reported. After $70 \mathrm{y}$ of rapid advances in the identification and effective treatment of many malignant cases with the introduction of potential drugs, such as azathioprine and methotrexate, which helped in the treatment of several tumors that were untreatable previously or only cured through radiation and surgery [3]. The disadvantage of conventional drugs is mainly because of their nonspecific cytotoxicity to tumor cells, which leads narrow therapeutic window and low therapeutic index [4]. Due to the severity of this disease and elevated cytotoxicity profiles of present drugs, there is an urgent need for a new drug with less cytotoxicity, safe, and more effective and efficient to treat the disease.

The 1, 2, 4-triazoles chemistry and their fused heterocyclic derivatives have received considerable attention owing to their effective biological significance. A large number of 1, 2, 4-triazole derivatives, incorporated with a wide variety of medicinally important drug candidates exhibit anticancer, antimicrobial [5] and analgesic [6]properties. Literature survey revealed that chemotherapeutic agents, such as vorozole, letrozole and anastrozole consisting of substituted 1, 2, 4-triazole ring, are presently being used in the treatment of breast cancer [7], additionally 1, 2, 4 triazole derivatives have been reported to inhibit enzymes responsible for the expression of tumors such as aromatase [8] and tubulin polymerase [9].
Keeping in view of the above-mentioned facts, and in continuation of our research on coupled heterocycles [10, 11], for biological evaluation, we focused on the synthesis of structurally distinct novel 2-(1-benzofuran-2-yl)-4-(5-phenyl-4H-1, 2, 4-triazol-3-yl) quinoline derivatives $3(\mathrm{a}-\mathrm{m})$, for in vitro antiproliferative study on different cancer cell lines viz. MCF-7 (breast cancer), K562 (leukemic cancer), HeLa (cervical cancer), Colo205 (colorectal adenocarcinoma) and HepG2 (Hepatocellular carcinoma) by MTT assay $[11,12]$. The in silico molecular docking analysis was conducted to identify the binding ability of the ligands $3(\mathrm{a}-\mathrm{m})$ with glucose-6-phosphate dehydrogenase (G6PDH) [13] to correlate with their in vitro antiproliferative activity as overexpression of G6PDH show resistance to apoptosis and pro-survival role in cancer cells. Similarly, In silico Absorption-Distribution-Metabolism-Excretion (ADME) analysis of the compounds was performed to check their drug likeliness property and human intestinal absorption (HIA) [14].

\section{MATERIALS AND METHODS}

\section{Materials}

Chemicals used in the synthesis of compounds were purchased from Alfa Aesar and Spectrochem Pvt. Melting points were determined in open capillary and are uncorrected. The purity compounds and the progress of the reaction were checked on precoated silica gel TLC plates. IR spectra were recorded with $\mathrm{KBr}$ pellet method on NicoletImpact-410 FT-IR spectrometer. ${ }^{1} \mathrm{H}$ NMR spectra were recorded on a JEOL FT-NMR (400 MHz) spectrometer, TMS as an internal standard. The chemical shifts are represented in $\delta$ units, and the coupling 
constant J was measured in $\mathrm{Hz}$. The mass spectra were recorded on a JEOL SX 102/DA-6000 (10 kV) FAB mass spectrometer.

\section{Procedure for synthesis of 2-(1-benzofuran-2-yl) quinoline-4- carbohydrazide}

The compound was synthesized by earlier unreported method [15]. The formation of the compound was confirmed by comparing its melting point with literature value (mp: $260-264^{\circ} \mathrm{C}$ )

General procedure for the synthesis of 2-(1-benzofuran-2-yl)-4(5-phenyl-4H-1, 2, 4-triazol-3-yl) quinoline 3(a-m)

Accurately weighed 2-(1-benzofuran-2-yl) quinoline-4-carbohydrazide $0.050 \mathrm{~g}(1 \mathrm{mmol})$ and ammonium acetate $0.038 \mathrm{~g} \mathrm{(5}$ $\mathrm{mmol}$ ) was dissolved in $10 \mathrm{ml}$ glacial acetic acid and kept for stirring (10 $\mathrm{min}$ ), this was followed by the addition of $1 \mathrm{mmol}$ substituted aromatic and heterocyclic aldehydes $2(\mathrm{a}-\mathrm{m})$. The reaction mixture was stirred at ambient temperature for about $24 \mathrm{~h}$. The solid separated was filtered, washed with water, dried and recrystallized by using ethanol to yield title compounds $3(\mathrm{a}-\mathrm{m})$.

\section{2-(1-benzofuran-2-yl)-4-(5-phenyl-4H-1, 2, 4-triazol-3-yl) quino- lone (3a)}

Mp: $280-282{ }^{\circ} \mathrm{C}$; Yield: $82 \%$; IR $\mathrm{v}_{\max }\left(\mathrm{KBr}, \mathrm{cm}^{-1}\right): 3200-3280(-\mathrm{N}-\mathrm{H}$ Stretch of triazole), 3050-3100 (Aromatic-C-H Stretch); ${ }^{1} \mathrm{H}$ NMR (400 MHz, DMSO-d $\left.\mathrm{d}_{6}, \delta, \mathrm{ppm}\right): 12.32(\mathrm{~s}, 1 \mathrm{H},-\mathrm{N}-\mathrm{H}$ of triazole), 8.37$8.40(\mathrm{~d}, 1 \mathrm{H}, J=12 \mathrm{~Hz}, \mathrm{Ar}-\mathrm{H}), 8.14-8.22(\mathrm{q}, 2 \mathrm{H}, J=32 \mathrm{~Hz}, \mathrm{Ar}-\mathrm{H}), 7.64-$ $7.97(\mathrm{~m}, 7 \mathrm{H}, \mathrm{Ar}-\mathrm{H}), 7.42-7.50(\mathrm{~m}, 3 \mathrm{H}, \mathrm{Ar}-\mathrm{H}), 7.33-7.37$ (t, $1 \mathrm{H}, J=16$ $\mathrm{Hz}, \mathrm{Ar}-\mathrm{H})$, 7.19-7.25 (m, 1H, Ar-H); MS: $m / z 389$ (M+1).

\section{2-(1-benzofuran-2-yl)-4-[5-(4-chlorophenyl)-4H-1, 2, 4-triazol-3-yl]} quinoline (3b)

Mp: $385-387^{\circ} \mathrm{C}$; Yield: 78 \%; IR $\mathrm{v}_{\max }\left(\mathrm{KBr}, \mathrm{cm}^{-1}\right): 3280-3400(-\mathrm{N}-\mathrm{H}$ Stretch of triazole), 3150-3200 (Aromatic-C-H Stretch); ${ }^{1} \mathrm{H}$ NMR (400 MHz, DMSO-d $6, \delta, p p m): 12.35(\mathrm{~s}, 1 \mathrm{H},-\mathrm{N}-\mathrm{H}$ of triazole), 8.358.37 (d, $2 \mathrm{H}, \mathrm{J}=8 \mathrm{~Hz}, \mathrm{Ar}-\mathrm{H}), 8.12-8.20$ (m, 3H, Ar-H), 7.95 (s, 1H, Ar$\mathrm{H})$, 7.75-7.92 (m, 7H, Ar-H), 7.19-7.21 (d, $1 \mathrm{H}, J=8 \mathrm{~Hz}, \mathrm{Ar}-\mathrm{H})$; [13]C NMR (100 MHz, DMSO-d 6 , $\delta$, ppm): 162.51, 155.01, 154.09, 147.91, $147.86,147.65,143.87,141.32,134.94,132.90,130.88$, $129.48,129.06,128.99,128.86,128.24,128.00,126.26,125.27$, $123.71,123.66,122.26,116.70,111.72,107.54 ; M S: ~ m / z ~ 424(M+1)$.

\section{4-\{5-[2-(1-benzofuran-2-yl) quinolin-4-yl]-4H-1, 2, 4-triazol-3-yl\} phenol (3c)}

Mp: 308-310 ${ }^{\circ}$; Yield: $67 \%$; IR $v_{\max }\left(\mathrm{KBr}, \mathrm{cm}^{-1}\right)$ : 3300-3450 (-N-H Stretch of triazole), 3210-3280 (Aromatic-O-H Sretch), 3050-3110 (Aromatic-C-H Stretch); ${ }^{1} \mathrm{H}$ NMR (400 MHz, DMSO-d $\left.6, \delta, \mathrm{ppm}\right): 12.07$ (s, $1 \mathrm{H},-\mathrm{N}-\mathrm{H}$ of triazole), 8.15-8.18 (m, 3H, $\operatorname{Ar}-\mathrm{H}), 7.95(\mathrm{~s}, 1 \mathrm{H}$, Phenolic-O-H), 7.84-7.91 (m, 3H, Ar-H), 7.75-7.82 (m, 3H, Ar-H), 7.31-7.36 (q, $2 \mathrm{H}, J=20 \mathrm{~Hz}, \mathrm{Ar}-\mathrm{H}), 7.01-7.03(\mathrm{~d}, 1 \mathrm{H}, J=8 \mathrm{~Hz}, \mathrm{Ar}-\mathrm{H})$, 6.85-6.87 (d, 2H, J = 8 Hz, Ar-H); [13]C NMR (100 MHz, DMSO-d $6, \delta$, ppm): $162.12,159.76,155.00,154.13,149.19,141.67,130.82$, $129.16,128.25,127.92,126.23,125.35,123.71,122.25,116.60$, 115.79, 111.72;MS: $m / z \quad 405(\mathrm{M}+1)$.

2-(1-benzofuran-2-yl)-4-[5-(4-methoxyphenyl)-4H-1, 2, 4-triazol-3yl] quinolone (3d)

Mp: 276-278 ${ }^{\circ} \mathrm{C}$; Yield: $74 \%$; IR $\mathrm{v}_{\max }\left(\mathrm{KBr}, \mathrm{cm}^{-1}\right): 3400-3450(-\mathrm{N}-\mathrm{H}$ Stretch of triazole), 3180-3250 (Aromatic-C-H Stretch), 2952-2990 (Aliphatic-C-H Stretch); ${ }^{1} \mathrm{H}$ NMR (400 MHz, DMSO-d $\left.{ }_{6}, \delta, \mathrm{ppm}\right): 12.15$ (s,1H,-N-H of triazole), 8.32-8.33 (d,2H, $J=4 \mathrm{~Hz}, \mathrm{Ar}-\mathrm{H}), 8.15-8.21$ $(\mathrm{m}, 3 \mathrm{H}, \mathrm{Ar}-\mathrm{H}), 7.84-7.92(\mathrm{~m}, 2 \mathrm{H}, \mathrm{Ar}-\mathrm{H}), 7.75-7.82(\mathrm{~m}, 2 \mathrm{H}, \mathrm{Ar}-\mathrm{H}), 7.70-$ $7.74(\mathrm{~m}, 2 \mathrm{H}, \mathrm{Ar}-\mathrm{H}), 7.33-7.37$ (q,1H, $J=16 \mathrm{~Hz}, \mathrm{Ar}-\mathrm{H}), 7.04-7.07$ (d, $2 \mathrm{H}$, $J=12 \mathrm{~Hz}, \mathrm{Ar}-\mathrm{H}), 3.82$ (s,3H,-O-CH $)$; [13]C NMR (100 MHz, DMSO-d 6 , $\delta$, ppm): $162.23,161.13,155.00,154.11,148.80,147.85,147.66$, $141.57,130.82,130.55,129.44,128.98,128.14,127.92,126.45$, $126.22,125.32,123.70,122.25,116.62,114.43,114.22,111.70$, $107.50,107.20,36.68\left(-0-\mathrm{CH}_{3}\right)$.

2-\{5-[2-(1-benzofuran-2-yl) quinolin-4-yl]-4H-1, 2, 4-triazol-3-yl\} phenol (3e)

Mp: 304-306 ${ }^{\circ}$; Yield: $85 \%$; IR $\mathrm{v}_{\max }\left(\mathrm{KBr}, \mathrm{cm}^{-1}\right): 3325-3478(-\mathrm{N}-\mathrm{H}$ Stretch of triazole), 3187-3300 (Aromatic-O-H Stretch), 3080-3100
(Aromatic-C-H Stretch); ${ }^{1} \mathrm{H}$ NMR (400 MHz, DMSO-d $\left.6, \delta, \mathrm{ppm}\right): 12.47$ (s,1H,-N-H of triazole), 8.36-8.39 (d, $1 \mathrm{H}, J=12 \mathrm{~Hz}, \mathrm{Ar}-\mathrm{H}), 8.22-8.24$ $(\mathrm{d}, 1 \mathrm{H}, J=8 \mathrm{~Hz}, \mathrm{Ar}-\mathrm{H}), 8.17-8.19(\mathrm{~m}, 1 \mathrm{H}, \mathrm{Ar}-\mathrm{H}), 7.96$ (s,1H, Phenolic-0H), 7.84-7.92 (m,2H, Ar-H), 7.76-7.81 (m,2H, Ar-H), 7.69-7.73 (m,1H, Ar-H), 7.63-7.65 (m,1H, Ar-H), 7.43-7.47 (m,1H, Ar-H), 7.31-7.37 (m,2H, Ar-H), 6.94-6.97 (m,2H, Ar-H); [13]C NMR (100 MHz, DMSO$\left.\mathrm{d}_{6}, \delta, \mathrm{ppm}\right): 162.20,157.47,156.44,155.02,154.20,148.73,147.87$, $144.21,140.93,131.86,130.91,129.04,128.26,127.50,126.28$, $125.15,123.68,122.27,119.50,118.74,116.83,116.07,115.86$, 111.72, 107.56;MS: $m / z \quad 405(\mathrm{M}+1)$.

4-(5-(2-(benzofuran-2-yl) quinolin-4-yl)-4H-1, 2, 4-triazol-3-yl)$\mathrm{N}, \mathrm{N}$ dimethyl benzenamine (3f)

Mp: 296-298 ${ }^{\circ} \mathrm{C}$; Yield: 65 \%; IR $\mathrm{v}_{\max }\left(\mathrm{KBr}, \mathrm{cm}^{-1}\right): 3320-3480(-\mathrm{N}-\mathrm{H}$ Stretch of triazole and N, N-dimethyl), 3050-3150 (Aromatic-C-H Stretch), 2920-2960 (Aliphatic-C-H Stretch); ${ }^{1} \mathrm{H}$ NMR $(400 \mathrm{MHz}$, DMSO-d $6, \delta, \mathrm{ppm}): 11.97(\mathrm{~s}, 1 \mathrm{H},-\mathrm{N}-\mathrm{H}$ of triazole), 8.30-8.31 (d,1H, $J=$ $4 \mathrm{~Hz}, \mathrm{Ar}-\mathrm{H}), 8.16-8.22(\mathrm{~m}, 4 \mathrm{H}, \mathrm{Ar}-\mathrm{H}), 7.84-7.95(\mathrm{~m}, 2 \mathrm{H}, \mathrm{Ar}-\mathrm{H}), 7.57-$ $7.62(\mathrm{~d}, 2 \mathrm{H}, J=20 \mathrm{~Hz}, \mathrm{Ar}-\mathrm{H}), 7.43-7.46(\mathrm{q}, 2 \mathrm{H}, J=12 \mathrm{~Hz}, \mathrm{Ar}-\mathrm{H}), 6.77$. $6.79(\mathrm{~d}, 2 \mathrm{H}, J=8 \mathrm{~Hz}, \mathrm{Ar}-\mathrm{H}), 6.49-6.51(\mathrm{~d}, 1 \mathrm{H}, J=8 \mathrm{~Hz}, \mathrm{Ar}-\mathrm{H}), 2.99$ (s,6H,-N, N-dimethyl); [13]C NMR (100 MHz, DMSO-d $6, \delta, p p m):$ $161.89,155.00,154.15,151.72,149.64,147.85,141.82,130.78$, $129.42,128.70,128.24,127.86,126.20,126.07,125.38,123.83$, $123.68,122.23,121.07,116.57,116.05,111.80,111.70,111.62$, 107.47, 107.14;MS: $m / z 432(\mathrm{M}+1)$.

2-(1-benzofuran-2-yl)-4-[5-(4-methylphenyl)-4H-1, 2, 4-triazol3-yl] quinoline $(3 \mathrm{~g})$

Mp: 252-254 ${ }^{\circ} \mathrm{C}$; Yield: 76 \%; IR $\mathrm{U}_{\max }\left(\mathrm{KBr}, \mathrm{cm}^{-1}\right): 3310-3460(-\mathrm{N}-\mathrm{H}$ Stretch of triazole), 3056-3140 (Aromatic-C-H Stretch), 2860-2910 (Aliphatic-C-H Stretch); ${ }^{1} \mathrm{H}$ NMR (400 MHz, DMSO-d $\left.6, \delta, p p m\right): 12.22$ (s, $1 \mathrm{H},-\mathrm{N}-\mathrm{H}$ of triazole), $8.09(\mathrm{~s}, 1 \mathrm{H}, \mathrm{Ar}-\mathrm{H}), 7.92-7.95(\mathrm{~d}, 3 \mathrm{H}, J=12 \mathrm{~Hz}$, $\mathrm{Ar}-\mathrm{H}), 7.88-7.91(\mathrm{~m}, 4 \mathrm{H}, \mathrm{Ar}-\mathrm{H}), 7.63-7.67(\mathrm{t}, 1 \mathrm{H}, J=16 \mathrm{~Hz}, \mathrm{Ar}-\mathrm{H}), 7.43-$ $7.47(\mathrm{~m}, 5 \mathrm{H}, \mathrm{Ar}-\mathrm{H}), 2.17$ (s,3H,-CH 3 p-methyl); [13]C NMR (100 MHz, DMSO- $\left._{6}, \delta, \mathrm{ppm}\right): 168.31,162.35,155.00,154.11,148.98,147.86$, $145.09,143.42,141.48,140.37,139.80,131.23,130.84,129.55$, $129.30,128.24,127.95,126.55,126.09,125.31,123.70,122.17$, 116.66, 107.51, 107.22, 30.68 (C of p-methyl); MS: m/z 403 (M+1).

2-(1-benzofuran-2-yl)-4-[5-(4-fluorophenyl)-4H-1, 2, 4-triazol3-yl] quinoline (3h)

Mp: 242-244 ${ }^{\circ}$ C; Yield: 89 \%; IR $v_{\max }\left(\mathrm{KBr}, \mathrm{cm}^{-1}\right)$ : 3410-3490 (-N-H Stretch of triazole), 3032-3090 (Aromatic-C-H Stretch); ${ }^{1} \mathrm{H}$ NMR $\left(400 \mathrm{MHz}, \mathrm{DMSO}-\mathrm{d}_{6}, \delta, \mathrm{ppm}\right): 12.30(\mathrm{~s}, 1 \mathrm{H},-\mathrm{N}-\mathrm{H}$ of triazole), $8.34-$ $8.38(\mathrm{~d}, 2 \mathrm{H}, J=16 \mathrm{~Hz}, \mathrm{Ar}-\mathrm{H}), 7.92-7.95(\mathrm{~d}, 1 \mathrm{H}, J=12 \mathrm{~Hz}, \mathrm{Ar}-\mathrm{H}), 7.61-$ $7.91(\mathrm{~m}, 8 \mathrm{H}, \mathrm{Ar}-\mathrm{H}), 7.43-7.47$ (m, 1H, Ar-H), 7.22-7.25 (m,1H, Ar-H), 7.03-7.07 (t,1H, $J=16 \mathrm{~Hz}, \mathrm{Ar}-\mathrm{H})$; [13]C NMR (100 MHz, DMSO-d ${ }_{6}, \delta$, ppm): 164.55, 162.43, 154.99, 147.89, 147.83, 143.36, 141.37, $130.81,130.53,129.58,129.49,128.65,127.92,127.59,126.19$, $126.05,125.24,123.66,122.21,116.61,115.87,115.67,111.66$, 107.45, 107.18;MS: $m / z 407(\mathrm{M}+1)$.

2-(1-benzofuran-2-yl)-4-[5-(3-nitrophenyl)-4H-1, 2, 4-triazol-3yl] quinoline (3i)

Mp: $232-234{ }^{\circ} \mathrm{C}$; Yield $62 \%$; IR $\mathrm{U}_{\max }\left(\mathrm{KBr}, \mathrm{cm}^{-1}\right): 3475-3340(-\mathrm{N}-\mathrm{H}$ Stretch of triazole), 3030-3110 (Aromatic-C-H Stretch), 1520-1530 (Asymmetric Stretch-NO ${ }_{2}$ ), 1310-1350 (Symmetric Stretch- $\mathrm{NO}_{2}$ ); ${ }^{1} \mathrm{H}$ NMR (400 MHz, DMSO-d $6, \delta, \mathrm{ppm}): 12.52(\mathrm{~s}, 1 \mathrm{H},-\mathrm{N}-\mathrm{H}$ of triazole), 8.29-8.32 (d, $1 \mathrm{H}, J=12 \mathrm{~Hz}, \mathrm{Ar}-\mathrm{H}), 8.18-8.25(\mathrm{~m}, 3 \mathrm{H}, \mathrm{Ar}-\mathrm{H}), 7.85-7.96$ $(\mathrm{m}, 2 \mathrm{H}, \mathrm{Ar}-\mathrm{H}), 7.69-7.81(\mathrm{~m}, 4 \mathrm{H}, \mathrm{Ar}-\mathrm{H}), 7.59-7.64(\mathrm{q}, 1 \mathrm{H}, J=20 \mathrm{~Hz}, \mathrm{Ar}-$ H), 7.40-7.53 (m,2H, Ar-H), 7.31-7.38 (m, 1H, Ar-H); [13]C NMR (100 MHz, DMSO-d $6, \delta$, ppm): $168.70,162.75,155.01,148.27,147.85$, $146.60,142.76,141.14,135.81,133.55,130.91,130.32,129.50$, $128.23,126.26,125.23,124.65,123.71,122.27,121.32,116.72$, 116.36, 111.71, 107.54, 107.29;MS: $m / z 434(\mathrm{M}+1)$.

4-\{5-[2-(1-benzofuran-2-yl) quinolin-4-yl]-4H-1, 2, 4-triazol-3yl\} benzene-1, 3-diol (3j)

Mp: 312-314 ${ }^{\circ} \mathrm{C}$; Yield $72 \%$; IR U $\max \left(\mathrm{KBr}, \mathrm{cm}^{-1}\right): 3365-3480(-\mathrm{N}-\mathrm{H}$ Stretch of triazole), 3180-3290 (Phenolic-O-H Sretch), 3020-3080 (Aromatic-C-H Stretch); ${ }^{1} \mathrm{H}$ NMR ( $400 \mathrm{MHz}$, DMSO-d $6, \delta, \mathrm{ppm}$ ): 12.27 $(\mathrm{s}, 1 \mathrm{H},-\mathrm{N}-\mathrm{H}$ of triazole $), 8.46(\mathrm{~s}, 1 \mathrm{H}$, Phenolic-O-H $), 8.35(\mathrm{~s}, 1 \mathrm{H}$, Phenolic-O-H), 8.12-8.23 (m,2H, Ar-H), 7.92-7.95 (d,1H, J = 12 Hz, Ar- 
H), 7.60-7.90 (m,5H, Ar-H), 7.32-7.47 (m,3H, Ar-H), 6.34-6.39 (t,2H, $J$ $=20 \mathrm{~Hz}, \mathrm{Ar}-\mathrm{H})$; [13]C NMR (100 MHz, DMSO-d $6, \delta, \mathrm{ppm}): 161.81$, $160.56,159.49,158.21,155.00,154.11,149.68,147.85,145.41$, $143.41,141.10,131.04,129.69,128.24,126.24,125.36,123.70$, $122.25,116.74,115.67,111.70,110.42,107.90,107.33,102.62 ; \mathrm{MS}$ : $m / z 421(\mathrm{M}+1)$.

2-(benzofuran-2-yl)-4-(5-(2-chloroquinolin-3-yl)-4H-1, 2, 4triazol-3-yl) quinoline (3k)

Mp: 218-220 ${ }^{\circ}$; ; Yield: $60 \%$; IR $v_{\max }\left(\mathrm{KBr}, \mathrm{cm}^{-1}\right): 3340-3475(-\mathrm{N}-\mathrm{H}$ Stretch of triazole), 3050-3120 (Aromatic-C-H Stretch); ${ }^{1} \mathrm{H}$ NMR (400 MHz, DMSO-d $\left.{ }_{6}, \delta, p p m\right): 12.68(\mathrm{~s}, 1 \mathrm{H},-\mathrm{N}-\mathrm{H}$ of triazole), 8.41-8.43 (d,1H, $J=8 \mathrm{~Hz}, \mathrm{Ar}-\mathrm{H}), 8.29-8.34(\mathrm{~d}, 1 \mathrm{H}, J=20 \mathrm{~Hz}, \mathrm{Ar}-\mathrm{H}), 8.19-8.25(\mathrm{q}, 2 \mathrm{H}, J=24$ $\mathrm{Hz}, \mathrm{Ar}-\mathrm{H}), 7.98-8.01(\mathrm{~d}, 2 \mathrm{H}, J=12 \mathrm{~Hz}, \mathrm{Ar}-\mathrm{H}), 7.85-7.94(\mathrm{~m}, 3 \mathrm{H}, \mathrm{Ar}-\mathrm{H})$, 7.71-7.82 (m, 4H, Ar-H), 7.42-7.48 (m,1H, Ar-H), 7.32-7.37 (q,1H, $J=20$ $\mathrm{Hz}, \mathrm{Ar}-\mathrm{H}$ ); [13]C NMR (100 MHz, DMSO-d $6, \delta, \mathrm{ppm}): 155.01,154.03$, $147.93,144.42,141.92,140.89,136.12,130.87,129.49,129.15$, $127.93,127.62,126.22,125.77,125.17,123.57,122.23,116.23$, 111.73, 107.56; $\left(\mathrm{C}_{28} \mathrm{H}_{16} \mathrm{~N}_{5} \mathrm{ClO}\right.$, 473.91); MS: $m / z 475(\mathrm{M}+1)$.

2-(1-benzofuran-2-yl)-4-[5-(1H-indol-3-yl)-4H-1, 2, 4-triazol-3yl] quinoline (31)

Mp: 319-321 ${ }^{\circ} \mathrm{C}$; Yield: 80 \%; IR $\mathrm{U}_{\max }\left(\mathrm{KBr}, \mathrm{cm}^{-1}\right): 3433-3458(-\mathrm{N}-\mathrm{H}$ Stretch of Indole), 3284-3320 (-N-H Stretch of Triazole), 3020-3086 (Aromatic-C-H Stretch); ${ }^{1} \mathrm{H}$ NMR ( $\left.400 \mathrm{MHz}, \mathrm{DMSO}_{-} \mathrm{d}_{6}, \delta, \mathrm{ppm}\right): 12.07$ (s, $1 \mathrm{H},-\mathrm{N}-\mathrm{H}$, triazole), $11.93(\mathrm{~s}, 1 \mathrm{H},-\mathrm{N}-\mathrm{H}$, indole), 8.17-8.26 (m, 6H, ArH), $7.937 .96(\mathrm{~d}, 1 \mathrm{H}, J=12 \mathrm{~Hz}, \mathrm{Ar}-\mathrm{H}), 7.58-7.62(\mathrm{t}, 1 \mathrm{H}, J=16 \mathrm{~Hz}, \mathrm{Ar}-$ H), 7.36-7.47 (m, 4H, Ar-H), 6.82-6.86 (t,1H, $J=16 \mathrm{~Hz}, \mathrm{Ar}-\mathrm{H}), 6.52-6.57$ $(\mathrm{d}, 1 \mathrm{H}, J=20 \mathrm{~Hz}, \mathrm{Ar}-\mathrm{H}), 6.24-6.27(\mathrm{t}, 1 \mathrm{H}, J=12 \mathrm{~Hz}, \mathrm{Ar}-\mathrm{H}) ;[13] \mathrm{C}$ NMR (100 MHz, DMSO-d 6 , $\delta$, ppm): 167.77, 161.74, 154.98, 154.19, 147.92, $147.68,145.92,144.18,142.11,141.52,137.09,131.07,129.42$, $128.27,127.58,126.20,123.69,123.59,122.75,122.03,120.59$, $116.59,116.08,111.91,111.68,111.40,107.48 ; M S: m / z ~ 428(M+1)$.

2-(benzofuran-2-yl)-4-(5-(benzofuran-2-yl) quinolin-4-yl)-4H1, 2, 4-triazol-3-yl) quinoline (3m)

Mp: 332-334 ${ }^{\circ}$ C; Yield: $64 \%$; ${ }^{1} \mathrm{H}$ NMR (DMSO- $\mathrm{d}_{6}, \delta, \mathrm{ppm}, 400 \mathrm{MHz}$ ): $12.81(\mathrm{~s}, 1 \mathrm{H},-\mathrm{N}-\mathrm{H}), 8.47-8.53(\mathrm{~d}, 1 \mathrm{H}, J=24 \mathrm{~Hz}, \mathrm{Ar}-\mathrm{H}), 8.15-8.30(\mathrm{~m}, 3 \mathrm{H}$, $\mathrm{Ar}-\mathrm{H})$, 7.87-7.99 (m,5H, Ar-H), 7.73-7.84 (m,6H, Ar-H), 7.64-7.69 (m, $2 \mathrm{H}, \mathrm{Ar}-\mathrm{H}), 7.55-7.61(\mathrm{~m}, 1 \mathrm{H}, \mathrm{Ar}-\mathrm{H}), 7.42-7.48(\mathrm{~m}, 2 \mathrm{H}, \mathrm{Ar}-\mathrm{H})$; MS: $\mathrm{m} / \mathrm{z}$ $556(\mathrm{M}+1)$.

\section{Biological activity}

\section{Evaluation of anti-proliferative activity}

The antiproliferative activity of synthesized compounds was carried against five different cancer cell lines using doxorubicin as a positive control by MTT assay $[11,12]$ (table 2). The cells lines were obtained from the Department of National Centre of Cell Sciences, Pune, India, and were cultured at a seeding density of $0.2 \times 106$ in DMEM/RPMI medium supplemented with $100 \mathrm{U} / \mathrm{ml}$ penicillin, $10 \%$ FBS and $100 \mu \mathrm{g} / \mathrm{ml}$ streptomycin, respectively and maintained in a humidified atmosphere with $5 \% \mathrm{CO}_{2}$ at $37{ }^{\circ} \mathrm{C}$. The samples were dissolved in dimethyl sulfoxide (DMSO; not exceeding the final concentration of $0.01 \%$ ) and further diluted in cell culture medium.

The antiproliferative respond of different molecules was assessed by MTT assay. Cells $(\sim 10,000)$ were plated in $200 \mu \mathrm{L}$ growth medium in the presence or absence of the molecule $(25,50,100$, and 200 $\mu \mathrm{g} / \mathrm{ml}$ ) in 96-well culture plates for $24 \mathrm{~h}$. Then the culture plates were centrifuged at $2000 \mathrm{rpm}$ for $10 \mathrm{~min}$ at room temperature. 100 $\mu \mathrm{L}$ of supernatant was discarded and, $20 \mu \mathrm{L}$ of MTT $(5 \mathrm{mg} / \mathrm{ml}$ in PBS) was added to each well and incubated for $4 \mathrm{~h}$ at $37^{\circ} \mathrm{C}$. The viability of the cells was determined using a spectrophotometer at $570 \mathrm{~nm}$. The IC50, that is, the concentration of the compound required to inhibit cell growth by $50 \%$, was determined.

\section{In silico studies}

\section{Molecular docking}

The synthesized ligands were drawn using Chem Draw (Version 10), 3D optimized using Frog v 2.14 [16], and were energy minimized for docking by merging the non-polar hydrogen and assigning Gastegier charges using Auto Dock Tools (ADT) 1.5.6. The X-ray crystal structure of G6PDH (PDB ID: 1XFF) with a resolution of $1.81 \AA$ was retrieved from the Protein Data Bank. The active site pocket consists of residues Cys 1, Trp 74, Thr 76, His 77, Gly 99 and Asp 123 reported earlier $[17,18]$. Thirteen ligands were docked to the receptor using Auto Dock 4; the ligand pose with lowest binding energy was extracted and aligned with receptor structure for visualization. The root mean square deviation (RMSD) of the overlapping structures was ascertained to confirm the docking procedure effectiveness.

\section{Absorption-distribution-metabolism-excretion (ADME) study}

The ADME properties of all the ligands $3(\mathrm{a}-\mathrm{m})$ were calculated by using web-based pre-ADMET tool Version 2.0. It predicts pharmaceutically applicable and physically significant descriptor properties of chemical molecules. Energy minimized ligands were given as a source and the chemical as well as biological descriptors relevance to (Lipinski rule of five) drug-likeliness [14] were analyzed.

\section{RESULTS AND DISCUSSION}

\section{Chemistry}

2-(1-benzofuran-2-yl)-4-(5-phenyl-4H-1, 2, 4-triazol-3-yl) quinoline derivatives $3(\mathrm{a}-\mathrm{m})$ were obtained by 2-(1-benzofuran-2-yl) quinoline-4-carbohydrazide upon reaction with substituted aromatic and heteroaromatic aldehydes $2(\mathrm{a}-\mathrm{m})$ using the catalytic amount of ammonium acetate and glacial acetic acid as a solvent (Scheme 1). The physical data of the compounds were shown in table 1 . The structures of compounds were confirmed by IR, ${ }^{1} \mathrm{H}-$ NMR, ${ }^{13} \mathrm{C}$-NMR and mass spectral analysis. The disappearance of characteristic absorption band between $1645-1690 \mathrm{~cm}^{-1}$ in the IR spectrum of the compound $3 \mathrm{~b}$ confirmed the absence of $\mathrm{C}=0$ group of the 2-(1-benzofuran-2-yl) quinoline-4-carbohydrazide and supports the formation of the title compounds.

The ${ }^{1} \mathrm{H}-\mathrm{NMR}$ spectrum of $3 \mathrm{~b}$ show a peak at $\delta 12.35 \mathrm{ppm}$ corresponding to the- $\mathrm{N}-\mathrm{H}$ proton of triazole, the peaks resonated around $\delta 7.19-8.37 \mathrm{ppm}$ corresponds to aromatic protons. The ${ }^{13} \mathrm{C}$ NMR spectrum of $3 \mathrm{~b}$ showed peaks between $\delta 107.54-162.51 \mathrm{ppm}$ confirms the formation of compounds $3 \mathrm{~b}$. The mass spectrum of the compound $3 \mathrm{~b}$ exhibit a molecular ion peak at $\mathrm{m} / \mathrm{z} 424.0[\mathrm{M}+1]$ corresponding to the molecular mass of the compound.

\section{Pharmacology}

\section{In vitro antiproliferative activity}

The in vitro antiproliferative activity of synthesized compounds 3(a$\mathrm{m})$ were determined by literature method $[11,12]$. Table 2 and fig. 1 . The results revealed that the compound 31 showed 44, 44, 38 and 37 $\%$ inhibition against MCF-7, HepG2, Colo205 and HeLa cell lines, respectively and the compounds $3 \mathrm{i}$ and $3 \mathrm{j}$ showed 49 and $42 \%$ inhibition against MCF-7 cell line. Whereas, the remaining compounds show less than $35 \%$ inhibition against the tested cancer cell lines at $10 \mu \mathrm{M}$ concentration.

The above results indicate that benzofuran, quinoline, and triazole moieties are essential for antiproliferative activity. The mnitrophenyl substituted triazole (3i) is the most active against MCF-7 cell line; this might be due to the presence of electron withdrawing nitro group on the meta position of the phenyl ring. The lipophilic nature of nitro-substituted molecules enables easy penetration into the cancer cell membrane and it may undergo reduction; this seems to fit in the active site of aromatase [19].

\section{In silico studies}

\section{Molecular docking}

The in silico molecular docking study helps to identify whether the molecular docking of G6PDH with synthesized ligands 3(a-m) provides a correlating information with their in vitro antiproliferative activity [13]. The molecular docking study revealed that compound $3 \mathrm{i}$ having the lowest binding energy $(-8.60 \mathrm{Kcal} / \mathrm{mol})$ in comparison to others, suggesting its potential to be as best potential inhibitor of G6PDH table 3. 


\begin{tabular}{llll}
\hline Compounds & $\mathbf{R}^{\mathbf{1}}$ & $\mathbf{R}^{2}$ & $\mathbf{R}^{3}$ \\
\hline $\mathrm{a}$ & $\mathrm{H}$ & $\mathrm{H}$ & $\mathrm{H}$ \\
$\mathrm{b}$ & $\mathrm{H}$ & $\mathrm{H}$ & $\mathrm{Cl}$ \\
$\mathrm{c}$ & $\mathrm{H}$ & $\mathrm{H}$ & $\mathrm{OCH}$ \\
$\mathrm{d}$ & $\mathrm{H}$ & $\mathrm{H}$ & $\mathrm{H}$ \\
$\mathrm{e}$ & $\mathrm{OH}$ & $\mathrm{H}$ & $\mathrm{N}, \mathrm{N}-$ dimethyl \\
$\mathrm{f}$ & $\mathrm{H}$ & $\mathrm{H}$ & $\mathrm{CH}$ \\
$\mathrm{g}$ & $\mathrm{H}$ & $\mathrm{H}$ & $\mathrm{F}$ \\
$\mathrm{h}$ & $\mathrm{H}$ & $\mathrm{H}$ & $\mathrm{H}$ \\
$\mathrm{i}$ & $\mathrm{H}$ & $\mathrm{NO}_{2}$ & $\mathrm{H}$ \\
\hline
\end{tabular}

R. T.-Room temperature

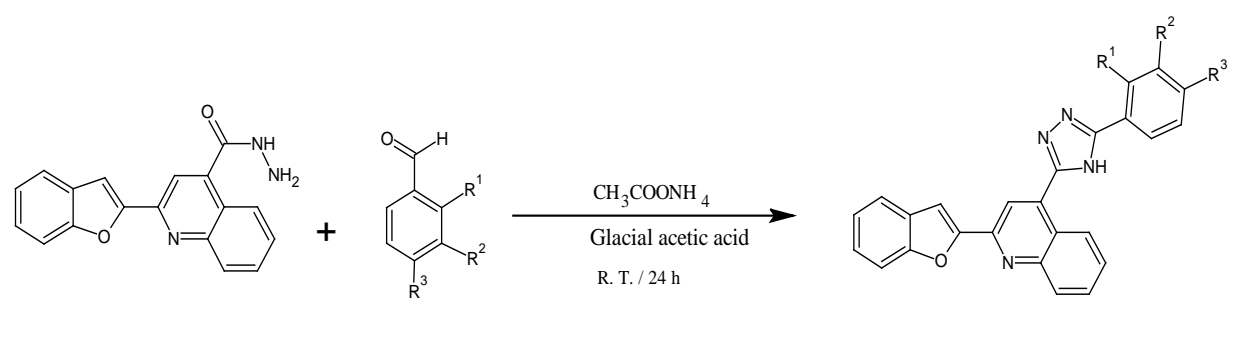

(1)

$2(\mathrm{a}-\mathrm{j})$

$3(a-j)$

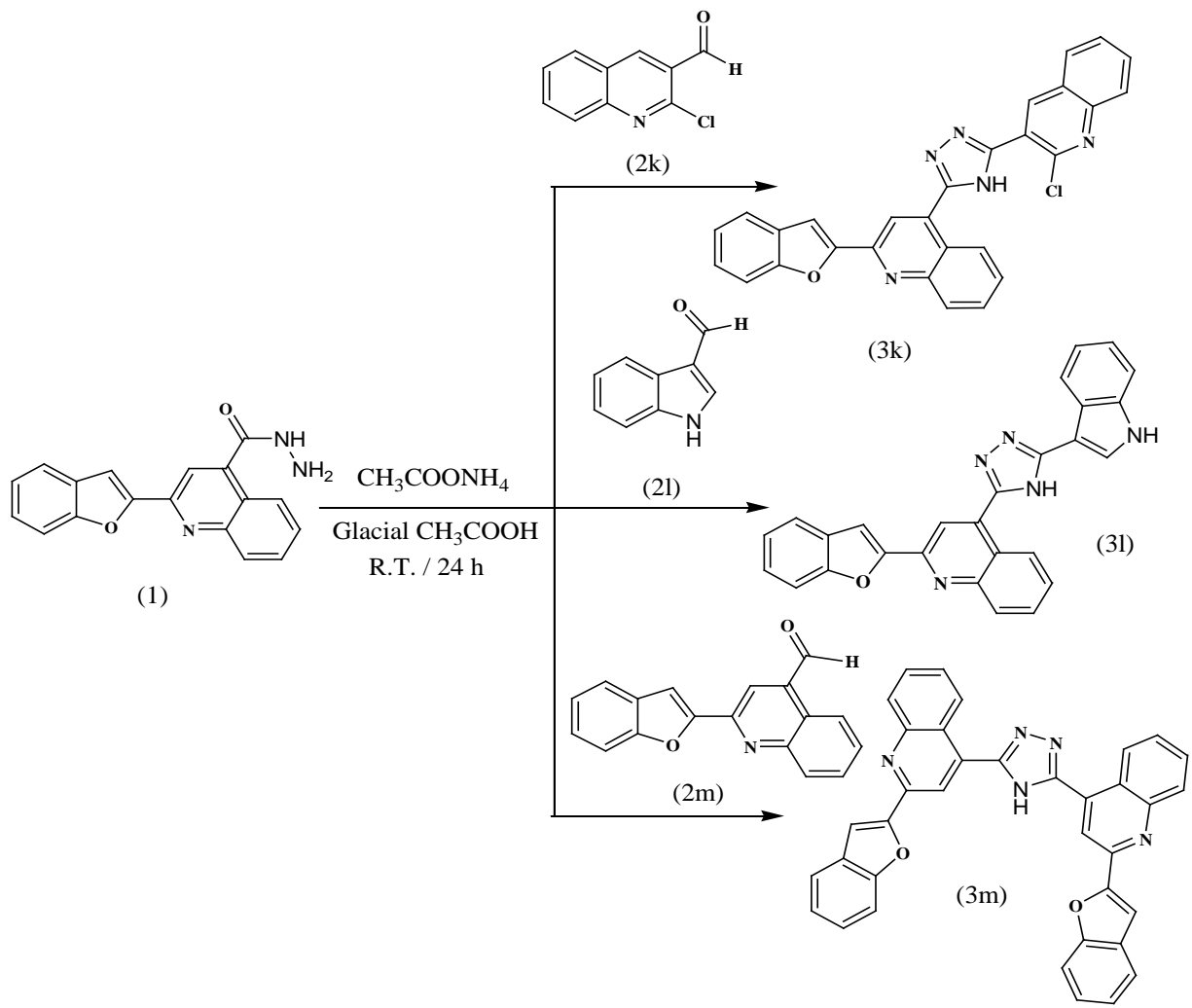

Scheme 1: Synthesis of 2-(1-benzofuran-2-yl)-4-(5-phenyl-4H-1, 2, 4-triazol-3-yl) quinoline and its derivatives 3(a-m)

Nevertheless, other derivatives also have good interaction with G6PDH via hydrogen bonding with key active site residues Arg 73, Trp 74, Thr 76, His 77 and His 86 (table 3) indicative of its inhibitory potential fig. 1. While the other ligands exhibit comparable interaction with active site of the receptors. The above results further strengthen and validate in vitro experimental results, of compound 3i. Hence, nitrogen heterocyclic along with benzofuran is very much essential for activity. The molecular docking analysis revealed that compound $3 \mathrm{i}(\mathrm{m}-$ nitrophenyl substituted) triazole has the lowest binding energy ( -8.60 $\mathrm{Kcal} / \mathrm{mol}$ ) in comparison to others suggesting its potential as a best potential inhibitor of G6PDH. Furthermore, ADME analysis revealed that compound $3 \mathrm{i}$ (m-nitrophenyl substituted) triazole does not violate any of Lipinski rule of five and also has best simulative human intestinal absorption of $95 \%$. The above findings clearly demonstrated that computational analysis was in good agreement with in vitro observations in concluding $3 \mathrm{i}$ (m-nitrophenyl substituted) triazole as the best potential inhibitor of G6PDH.

\section{Absorption-distribution-metabolism-excretion (ADME) analysis}

ADME analysis of the compounds was performed to check for the drug likeliness property and human intestinal absorption (HIA). The molecular properties of triazole derivatives $3(\mathrm{a}-\mathrm{m})$ are represented in table 4; it is evident from that the compounds $3(\mathrm{a}-\mathrm{l})$ did not violate any of the Lipinski rule of five [14] and are expected to be orally active. 
Table 1: Physical constant of 2-(1-benzofuran-2-yl)-4-(5-phenyl-4H-1, 2, 4-triazol-3-yl) quinoline derivatives 3(a-m)

\begin{tabular}{|c|c|c|c|c|c|c|}
\hline Sample code & R1 & R2 & R3 & M. For. & M. Wt. & M. pt. ${ }^{\circ} \mathrm{C}$ \\
\hline $3 a$ & $\mathrm{H}$ & $\mathrm{H}$ & $\mathrm{H}$ & $\mathrm{C}_{25} \mathrm{H}_{16} \mathrm{~N}_{4} \mathrm{O}$ & 388.42 & $280-282$ \\
\hline $3 b$ & $\mathrm{H}$ & $\mathrm{H}$ & $\mathrm{Cl}$ & $\mathrm{C}_{25} \mathrm{H}_{15} \mathrm{ClN}_{4} \mathrm{O}$ & 422.86 & $385-387$ \\
\hline $3 c$ & $\mathrm{H}$ & $\mathrm{H}$ & $\mathrm{OH}$ & $\mathrm{C}_{25} \mathrm{H}_{16} \mathrm{~N}_{4} \mathrm{O}_{2}$ & 404.42 & $308-310$ \\
\hline $3 d$ & $\mathrm{H}$ & $\mathrm{H}$ & $\mathrm{OCH} 3$ & $\mathrm{C}_{26} \mathrm{H}_{18} \mathrm{~N}_{4} \mathrm{O}_{2}$ & 418.44 & $276-278$ \\
\hline $3 e$ & $\mathrm{OH}$ & $\mathrm{H}$ & $\mathrm{H}$ & $\mathrm{C}_{25} \mathrm{H}_{16} \mathrm{~N}_{4} \mathrm{O}_{2}$ & 404.42 & $304-306$ \\
\hline $3 \mathrm{f}$ & $\mathrm{H}$ & $\mathrm{H}$ & $\mathrm{N}, \mathrm{N}$-dimethyl & $\mathrm{C}_{27} \mathrm{H}_{21} \mathrm{~N}_{5} \mathrm{O}$ & 431.48 & $296-298$ \\
\hline $3 g$ & $\mathrm{H}$ & $\mathrm{H}$ & $\mathrm{CH} 3$ & $\mathrm{C}_{26} \mathrm{H}_{18} \mathrm{~N}_{4} \mathrm{O}$ & 402.44 & $252-254$ \\
\hline $3 \mathrm{~h}$ & $\mathrm{H}$ & $\mathrm{H}$ & $\mathrm{F}$ & $\mathrm{C}_{25} \mathrm{H}_{15} \mathrm{FN}_{4} \mathrm{O}$ & 406.41 & $242-244$ \\
\hline $3 i$ & $\mathrm{H}$ & $\mathrm{NO} 2$ & $\mathrm{H}$ & $\mathrm{C}_{25} \mathrm{H}_{15} \mathrm{~N}_{5} \mathrm{O}_{3}$ & 433.41 & $232-234$ \\
\hline $3 \mathrm{j}$ & $\mathrm{OH}$ & $\mathrm{H}$ & $\mathrm{OH}$ & $\mathrm{C}_{25} \mathrm{H}_{16} \mathrm{~N}_{4} \mathrm{O}_{3}$ & 420.41 & $312-314$ \\
\hline $3 \mathrm{k}$ & & & & $\mathrm{C}_{28} \mathrm{H}_{16} \mathrm{ClN}_{5} \mathrm{O}$ & 473.91 & $218-220$ \\
\hline 31 & & & & $\mathrm{C}_{27} \mathrm{H}_{17} \mathrm{~N}_{5} \mathrm{O}$ & 427.45 & $319-321$ \\
\hline $3 \mathrm{~m}$ & & & & $\mathrm{C}_{36} \mathrm{H}_{21} \mathrm{~N}_{5} \mathrm{O}_{2}$ & 555.58 & $332-334$ \\
\hline
\end{tabular}

M. For.-Molecular formula, M. Wt.-Molecular weight, M. pt.-Melting point.

Table 2: Antiproliferative activity of 2-(1-benzofuran-2-yl)-4-(5-phenyl-4H-1, 2, 4-triazol-3-yl) quinoline and its derivatives 3(a-m)

\begin{tabular}{llllll}
\hline Sample code & K562 & MCF-7 & HeLa & Colo205 & Hepg2 \\
\cline { 2 - 6 } & \% Inhibition \pm SD & \% Inhibition \pm SD & \% Inhibition \pm SD & \% Inhibition \pm SD & \% Inhibition \pm SD \\
\hline 3a & NANA & $27.30 \pm 2.41$ & $24.63 \pm 2.01$ & $13.91 \pm 2.80$ & $11.21 \pm 2.04$ \\
3b & $4.00 \pm 2.92$ & $17.93 \pm 2.89$ & $21.78 \pm 2.33$ & $16.03 \pm 2.97$ & NANA \\
3c & $2.81 \pm 1.09$ & $14.06 \pm 2.65$ & $7.30 \pm 2.37$ & $8.49 \pm 3.66$ & $15.15 \pm 2.56$ \\
3d & $15.25 \pm 1.24$ & $21.19 \pm 2.97$ & $34.28 \pm 2.41$ & $5.89 \pm 2.32$ & $28.80 \pm 2.17$ \\
3e & $25.64 \pm 3.53$ & $24.55 \pm 3.41$ & $27.55 \pm 3.14$ & $12.42 \pm 3.91$ & $28.99 \pm 1.97$ \\
3f & NANA & $23.12 \pm 2.58$ & $26.09 \pm 1.52$ & $15.01 \pm 2.05$ & $31.10 \pm 2.95$ \\
3g & $4.43 \pm 1.19$ & $11.11 \pm 3.78$ & $-1.53 \pm 1.85$ & $-27.35 \pm 8.74$ & $11.41 \pm 2.96$ \\
3h & $14.50 \pm 1.04$ & NANA & NANA & $1.96 \pm 2.459$ & $7.27 \pm 2.48$ \\
3i & $13.63 \pm 0.99$ & $48.68 \pm 2.28$ & NANA & $6.76 \pm 12.95$ & $11.26 \pm 3.40$ \\
3j & $30.62 \pm 1.77$ & $42.27 \pm 2.84$ & $26.02 \pm 2.75$ & $13.67 \pm 2.24$ & $22.31 \pm 2.34$ \\
3k & $26.83 \pm 1.95$ & $15.28 \pm 1.31$ & NANA & NANA & NANA \\
31 & NANA & $43.59 \pm 3.43$ & $36.91 \pm 1.45$ & $38.05 \pm 1.89$ & $43.64 \pm 2.00$ \\
3m & $20.34 \pm 1.39$ & $25.47 \pm 3.06$ & $21.85 \pm 2.89$ & $10.69 \pm 1.53$ & $32.11 \pm 1.50$ \\
Doxorubicin & $95.57 \pm 2.22$ & $97.61 \pm 2.18$ & $97.16 \pm 2.27$ & $91.55 \pm 1.87$ & $92.35 \pm 1.56$ \\
\hline
\end{tabular}

NA-No activity, K562-Leukemic cancer, MCF-7-Breast cancer, HeLa-Cervical cancer, Colo205-Colorectal adreno carcinoma, Hepg2-Hepato cellular carcinoma, \pm SD-Standard deviation, $n=3$

Table 3: Docking score of the 2-(1-benzofuran-2-yl)-4-(5-phenyl-4H-1, 2, 4-triazol-3-yl) quinoline and its derivatives 3(a-m) with G6PDH

\begin{tabular}{lllll}
\hline Sample code & Binding energy (Kcal mol-1) & No. of hydrogen bonds & Bonding residues & Bond length (A $^{\circ}$ ) \\
\hline 3a & -4.82 & 1 & Cys1 & 2.9 \\
3b & -5.67 & 1 & Trp74 & 2.7 \\
3c & -5.04 & 4 & Arg73 & 2.1 \\
& & & Trp74 & 3.2 \\
& & & His97 & 2.1 \\
3d & 4 & Asp123 & 3.1 \\
& -6.06 & & Arg73 & 3.2 \\
& & & Trp74 & 3.9 \\
3e & & 4 & His86 & 2.8 and 3.2 \\
& & & Thr124 & 2.6 and 3.0 \\
3f & -5.54 & 1 & Cys1 & 3.0 \\
3h & -4.05 & 1 & Trp74 & 2.9 \\
3i & -4.48 & 1 & Cys1 & 2.6 \\
& -4.51 & 10 & Trp74 & $2.7,2.7$ and 2.9 \\
& -8.60 & & Trp74 & 2.7 and 2.9 \\
\end{tabular}




\begin{tabular}{|c|c|c|c|c|}
\hline & & & His86 & $\begin{array}{l}3.5 \text { and 3.0, } \\
3.1\end{array}$ \\
\hline \multirow[t]{5}{*}{$3 j$} & -6.22 & 5 & Cys1 & 2.7 \\
\hline & & & Arg73 & 2.8 \\
\hline & & & Trp74 His77 & 2.5 \\
\hline & & & Thr124 & 2.9 \\
\hline & & & & 3.2 \\
\hline $3 \mathrm{k}$ & -4.90 & - & - & - \\
\hline \multirow[t]{2}{*}{31} & -6.73 & 2 & Cys1 & 2.9 \\
\hline & & & Trp74 & 3.2 \\
\hline \multirow[t]{2}{*}{$3 m$} & -6.28 & 3 & Cys1 & 3.1 \\
\hline & & & Trp74 & 2.8 and 3.2 \\
\hline
\end{tabular}
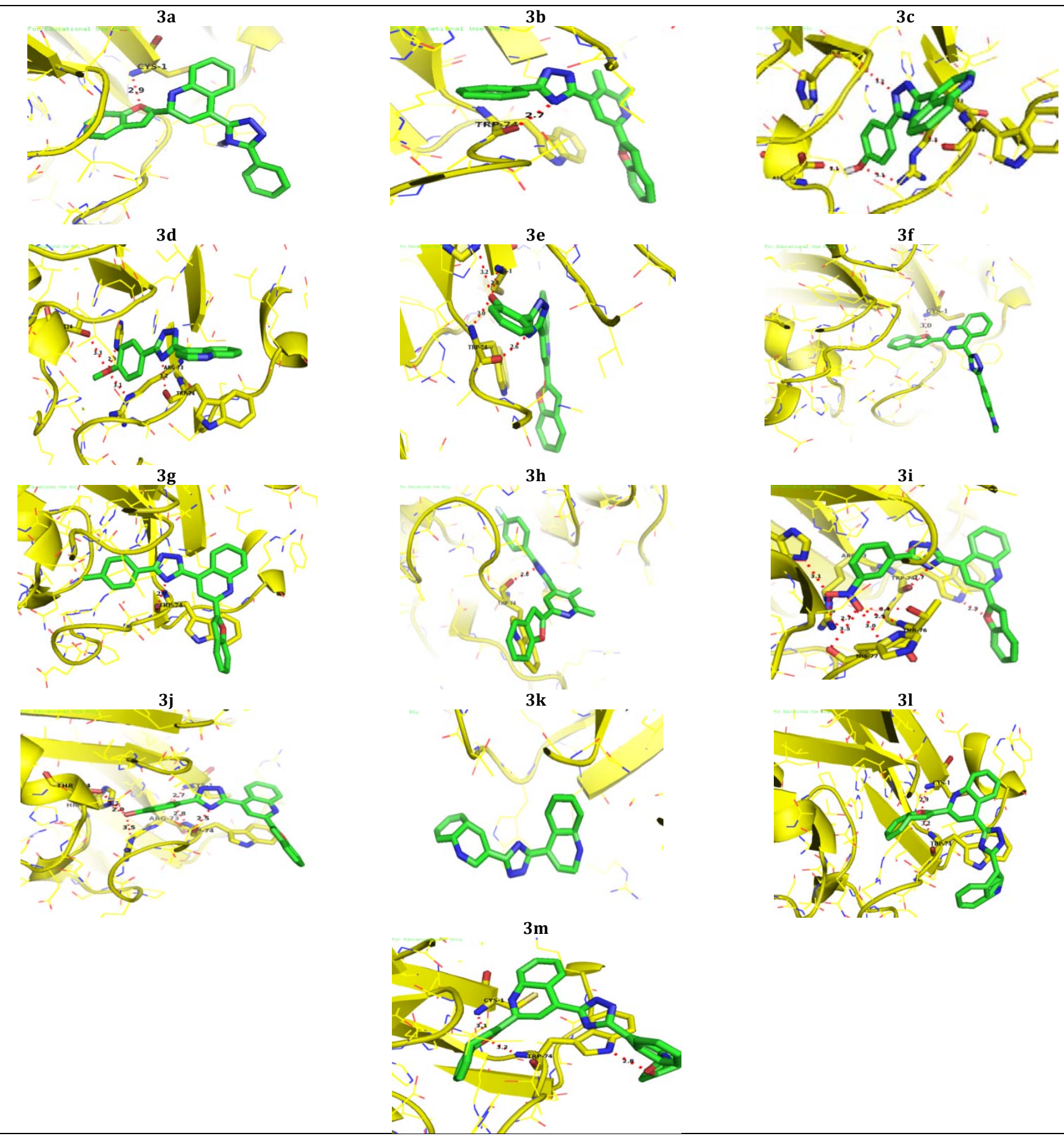

Fig. 1: Interaction of G6PDH with synthesized ligands of 2-(1-benzofuran-2-yl)-4-(5-phenyl-4H-1, 2, 4-triazol-3-yl) quinoline and its derivatives $3(\mathrm{a}-\mathrm{m})$, The protein is represented as yellow cartoons. The interacting residues (yellow color), The ligands (green color) are represented as sticks. The hydrogen bonds are represented as red dotted lines 
Table 4: ADME prediction of the 2-(1-benzofuran-2-yl)-4-(5-phenyl-4H-1, 2, 4-triazol-3-yl) quinoline and its derivatives 3(a-m)

\begin{tabular}{|c|c|c|c|c|c|c|c|c|}
\hline Sample code & Molecular formula & MW & $\log P$ & HBA & HBD & BBB & $\mathrm{Caco}_{2}$ & HIA \\
\hline $3 a$ & $\mathrm{C}_{25} \mathrm{H}_{16} \mathrm{~N}_{4} \mathrm{O}$ & 388.42 & 0 & 5 & 1 & 3.430 & 23.89 & 95.31 \\
\hline $3 b$ & $\mathrm{C}_{25} \mathrm{H}_{15} \mathrm{C}_{1} \mathrm{~N}_{4} \mathrm{O}$ & 422.86 & 0 & 5 & 1 & 5.494 & 43.56 & 95.50 \\
\hline $3 c$ & $\mathrm{C}_{25} \mathrm{H}_{16} \mathrm{~N}_{4} \mathrm{O}_{2}$ & 404.42 & 0 & 6 & 2 & 2.694 & 14.19 & 94.10 \\
\hline $3 d$ & $\mathrm{C}_{26} \mathrm{H}_{18} \mathrm{~N}_{4} \mathrm{O}_{2}$ & 418.44 & 0 & 6 & 1 & 1.758 & 29.27 & 95.73 \\
\hline $3 e$ & $\mathrm{C}_{25} \mathrm{H}_{16} \mathrm{~N}_{4} \mathrm{O}_{2}$ & 404.42 & 0 & 6 & 0 & 2.977 & 11.40 & 94.09 \\
\hline $3 f$ & $\mathrm{C}_{27} \mathrm{H}_{21} \mathrm{~N}_{5} \mathrm{O}$ & 431.48 & 0 & 6 & 0 & 3.200 & 24.54 & 95.61 \\
\hline $3 g$ & $\mathrm{C}_{26} \mathrm{H}_{18} \mathrm{~N}_{4} \mathrm{O}$ & 402.44 & 0 & 5 & 0 & 4.886 & 24.42 & 95.37 \\
\hline $3 \mathrm{~h}$ & $\mathrm{C}_{25} \mathrm{H}_{15} \mathrm{FN}_{4} \mathrm{O}$ & 406.41 & 0 & 5 & 0 & 4.028 & 44.02 & 95.32 \\
\hline $3 \mathrm{i}$ & $\mathrm{C}_{25} \mathrm{H}_{15} \mathrm{~N}_{5} \mathrm{O}_{3}$ & 433.41 & 0 & 5 & 0 & 0.044 & 10.60 & 95.16 \\
\hline $3 \mathrm{j}$ & $\mathrm{C}_{25} \mathrm{H}_{16} \mathrm{~N}_{4} \mathrm{O}_{3}$ & 420.41 & 0 & 7 & 0 & 1.637 & 1.98 & 92.26 \\
\hline $3 \mathrm{k}$ & $\mathrm{C}_{28} \mathrm{H}_{16} \mathrm{C}_{1} \mathrm{~N}_{5} \mathrm{O}$ & 473.91 & 0 & 6 & 0 & 2.233 & 35.00 & 96.27 \\
\hline 31 & $\mathrm{C}_{27} \mathrm{H}_{17} \mathrm{~N}_{5} \mathrm{O}$ & 427.45 & 0 & 6 & 0 & 5.100 & 22.58 & 93.64 \\
\hline $3 \mathrm{~m}$ & $\mathrm{C}_{36} \mathrm{H}_{21} \mathrm{~N}_{5} \mathrm{O}_{2}$ & 555.58 & 0 & 7 & 0 & 0.972 & 23.06 & 96.90 \\
\hline
\end{tabular}

The mw-molecular weight of the compound, LogP-Partition coefficient of octanol/water, HBA-No. Of hydrogen bond acceptor, HBD-No. of hydrogen bond donor, BBB-Blood brain barrier $\left(\mathrm{C}_{\text {brain }} / \mathrm{C}_{\text {blood }}\right)>2$-High absorption to CNS; 2.0-1.0-Medium absorption to CNS, $<1$-Less absorption to CNS, Caco2In vitro Caco 2 cell permeability $(\mathrm{nm} / \mathrm{s})<4$-low permeability, 4-70-medium permeability, $>70$ high permeability, HIA-Human Intestinal absorption (>70\%-high oral absorptions)

\section{CONCLUSION}

In the present investigation, we have demonstrated an effective strategy for the synthesis of functionalized 2-(1-benzofuran-2-yl)-4(5-phenyl-4H-1, 2, 4-triazol-3-yl) quinoline and its derivatives in good yield and evaluated for their antiproliferative activity, in silico molecular docking and ADME studies. The antiproliferative studies suggest that triazole containing indole ring 31 showed good \% inhibition against tested cancer cell lines, while m-nitrophenyl substituted triazole $3 \mathrm{i}$ and o and p-dihydroxy phenyl substituted triazole 3j exhibited good \% inhibition against MCF-7 cell line.

\section{ACKNOWLEDGEMENT}

The authors are thankful to Kuvempu University, for providing necessary facilities to carry out the present work. The author MK thanks to DST-WOSA and School of Bioscience, University of Hyderabad, Telangana for facilities to carry out screening.

\section{CONFLICT OF INTERESTS}

The authors declare that there is no conflict of interest.

\section{REFERENCES}

1. Jemal A, Center MM, De Santis C, Ward EM. Global patterns of cancer incidence and mortality rates and trends. Cancer Epidemiol Biomarkers Prev 2010;19:1893-907.

2. Ferlay J, Soerjomataram I, Dikshit R, Eser S, Mathers C, Rebelo $\mathrm{M}$, et al. Cancer incidence and mortality worldwide: sources, methods and major patterns in GLOBOCAN 2012. Int J Cancer 2015;136:359-86.

3. Papac RJ. Origins of cancer therapy. Yale J Biol Med 2001;74:391-8.

4. Frei EIII, Elias A, Wheeler, Richardson P, Hryniuk W. The relationship between high-dose treatment and combination chemotherapy: the concept of summation dose intensity. Clin Cancer Res 1998;4:2027-37.

5. Padmavathi V, Reddy GS, Padmaja A, Kondaiah P, Ali-Shazia. Synthesis, antimicrobial and cytotoxic activities of 1,3,4oxadiazoles, 1,3,4-thiadiazoles and 1,2, 4-triazoles. Eur J Med Chem 2009;44:2106-12.

6. Mathew V, Keshavayya J, Vaidya VP, Giles D. Studies on the synthesis and pharmacological activities of 3, 6-disubstituted1,2,4-triazolo[3,4-b]-1,3,4-thiadiazoles and their dihydro analogues. Eur J Med Chem 2007;42:823-40.

7. Clemons M, Coleman RE, Verma S. Aromatase inhibitors in the adjuvant setting: bringing the gold to a standard?. Cancer Treat Rev 2004;30:325-32.

8. Demirbas N, Karaoglu SA, Demirbas A, Sancak K. Synthesis and antimicrobial activities of some new 1-(5-phenylamino$[1,3,4]$ thiadiazol-2-yl)methyl-5-oxo-[1,2,4] triazole and 1-(4- phenyl-5-thioxo-[1,2,4] triazol-3-yl)methyl-5-oxo-[1,2,4] triazole derivatives. Eur J Med Chem 2004;39:793-804.

9. Zhang Q, Peng Y, Wang XI, Keenan SM, Arora S, Welsh WJ. Highly potent triazole based tubulin polymerization inhibitors. J Med Chem 2007;50:749-54.

10. Satyanarayan ND, Santoshkumar S, Sheelavanth S, Yadav DB, Anantacharya R, Sandeep T. Antitubercular, antibacterial and molecular docking studies of new 2 (naphtha [2,1-] furan-2-yl) quinoline-4-carboxylic acids and their esters. Inventi Impact: Med Chem 2016;2016:75-83.

11. Anantacharya $\mathrm{R}$, Manjulatha $\mathrm{K}$, Satyanarayan $\mathrm{ND}$, Santoshkumar S, Kaviraj MY. Antiproliferative, DNA cleavage, and ADMET study of substituted 2-(1-benzofuran $2 \mathrm{yl}$ ) quinoline-4-carboxylic acid and its esters. Cogent Chem 2016;2:1158382.

12. Manjunatha K, Siddappa, Manjulatha K, Satyanarayan ND, Kaviraj MY, Adarsha HJ. Anti-proliferative and ADMET screening of novel 3-(1H-indol-3-yl) 1, 3-diphenylpropan1-one derivatives. Cogent Chem 2016;2. http://doi.org/10.1080/ 23312009.2016.1172542

13. Riganti C, Gazzano E, Polimeni M, Aldieri E, Ghigo D. The pentose phosphate pathway: an antioxidant defense and a crossroad in tumor cell fate. Free Radical Biol Med 2012;53:421-36.

14. Lipinski CA, Lombardo F, Dominy BW, Feeney PJ. Experimental and computational approaches to estimate solubility and permeability in drug discovery and development settings. Adv Drug Delivery Rev 2001;46:3-26.

15. Sheelavanth Shanker Rao. Ph. D. Thesis, Kuvempu University; 2013.

16. Leite TB, Gomes D, Miteva MA, Chomilier J, Villoutreix BO, Tufféry P. Frog: a free online drug 3D conformation generator. Nucleic Acids Res 2007;35:568-72.

17. Wojciechowski M, Milewski S, Mazerski J, Borowski E. Glucosamine-6-phosphate synthase, a novel target for antifungal agents. Molecular modelling studies in drug design. Acta Biochim Pol 2005;52:647-53.

18. Banerjee K, Gupta U, Gupta S, Wadhwa G, Gabrani R, Sharma SK, et al. Molecular docking of glucosamine-6-phosphate synthase in rhizopus oryzae. Bioinformation 2011;7:285-90.

19. Chen S, Kao YC, Laughton CA. Binding characteristics of aromatase inhibitors and phytoestrogens to human aromatase. J Steroid Biochem Mol Biol 1997;61:107-15.

\section{How to cite this article}

- Santoshkumar S, Manjulatha K, Satyanarayan ND, Anantacharya R, Harishkumar S, Harishkumar HN, Yallappa S, Dhananjaya BL. Antiproliferative, adme and potential in silico G6PDH inhibitory activity of novel 2-(1-benzofuran-2-YL)-4-(5-phenyl-4H-1, 2, 4triazol-3-YL) quinoline derivatives. Int J Pharm Pharm Sci 2016;8(11):313-319. 